\title{
Erratum to: Rapidly Progressing Malignant Insulinoma Presented with Multiple Liver Metastases: A Case Report
}

\author{
Askin Erdogan • Fatih Kose • Hampar Akkaya • \\ Neslihan Bascil Tutuncu • Ozgur Ozyilkan
}

Published online: 21 September 2010

(C) Springer Science+Business Media, LLC 2010

Erratum to: J Gastrointest Canc

DOI 10.1007/s12029-010-9157-9

The online published version of this article presented the author names erroneously. The given names and the surnames should be as follows: Askin Erdogan, Fatih Kose, Hampar Akkaya, Neslihan Bascil Tutuncu and Ozgur Ozyilkan.

The online version of the original article can be found at http://dx.doi. org/10.1007/s12029-010-9157-9.

\footnotetext{
A. Erdogan

Departments of Gastroenterology, Baskent University,

Ankara, Turkey

F. Kose $\cdot$ O. Ozyilkan

Department of Medical Oncology, Baskent University,

Ankara, Turkey

H. Akkaya

Department of Pathology, Baskent University,

Ankara, Turkey

N. B. Tutuncu

Endocrinology, Baskent University,

Ankara, Turkey

F. Kose $(\bowtie)$

Adana Teaching and Medical Research Center,

Baskent University,

01120 Adana, Turkey

e-mail: fatihkose@gmail.com
} 